\title{
Sønderjylland 1930.
}

Af Thade Petersen.

\section{Gransen.}

I 1930 nermede Gransespørgsm a a l t sig øjensynligt endnu mere til det rette Leje, idet der fra begge Sider faldt Ord om Modparten, der bar Præg af voksende Forstataelse. Ved Nytatarstide offentliggjorde Gaardejer Haus Smidt i Kollund en Artikel on Hjemmetyskerne, lwori han sogte at fremdrage Punkter, der var fælles for dem og os og at paapege Fejl i det almindelige danske Syn paa dem. (11. $\left.\left.{ }^{30} / 1\right) .^{*}\right)$ Fra modsat Side begyndte der snart at lyde tilsvarende Toner. "Nordschl. Ztg." skrev sauledes i den Anledning, at der i Virkeligheden nu er godt Samarbejde mellem Danske og Tyske i Byraad, Menighedsraad og Skolekommissioner (H. ${ }^{3 / 2}$ ). Imidlertid rejser den gamle Adam dog ogsaa Hovedet paa ny ved given Lejlighed. Saaledes rejser "Fl. Nachr.« til 10-Aarsdag for Afstemningen i 2. Zone en hadsk Agitation mod Danskerne. Den støttes deri af Justitsraad Löhmann, mens Redaktør Ernst Schröder og andre tager til Genmæle mod dem (H. ${ }^{10 / 3},{ }^{11 / 3}$, Av. ${ }^{11 / 3}$ ). Af særlig Betydning var det, at den tyske Gesandt v. Hassel ved sin Bortrejse fra Kgbenhavn sagde, at Granseproblemet aldrig mere vilde blive et Spørgsmaal af magtpolitisk Natur (H. ${ }^{27} /{ }^{2},{ }^{2} \mathrm{~s}$ ).

Som dødfødt Projekt opstod paa tysk Side en Tanke om et $\mathrm{Gr} æ \mathrm{nseb} \mathbf{b}$ te paa $10 \mathrm{klm}$ med fri Færdsel (H. ${ }^{17} / \mathrm{g}$ ).

(Igsaa mellem $\mathrm{D}$ anske ind by rdes viser det sig. at Spørgsmaglet om Grænsedragningen har mistet sin Bitterhed, saa at de kan samles i Glæden over det vundne og i Arbejdet for at bevare, hvad der endinu er udsat. De danske Foreninger i Flenshorg og (megn sendte Nordslesvig en Hilsen til Afstemningsfesterne (H. ${ }^{\mathrm{H}} / 2,{ }^{10} / 2$ ) og modtog den 14. Marts Genhilsen og Lofte fra de nationale Foreningers Seksmandsudvalg (H. ${ }^{14} / 3$ ).

Der holdtes i Tiaaret for Afstemningen op imod 150

*) $\mathrm{H}=$ Hejmdal 1930, Av. = Flensborg Avis 1930, L = Nordslesvigsk Landbrugs- og Mejeritidende 1930, Ber. = Trykt Beretning fra velkommende Institution 1930. 
F e s t e r med ca. 25,000 Deltagere i Nordslesvig $\left(\mathrm{H},{ }^{11},{ }^{2},{ }^{12} / 2\right.$, ${ }^{13} / 2$ ). I Aarets Lob fremdroges i det hele et Værld af glade Minder vedrørende Genforeningen, saaledes isin' ${ }^{2}$. Maj, da Soldater, Gendarmer, Post osv. drog ind $\mathbf{i}$ Landet $(\mathbf{H}$. $\left.{ }^{101} / 2,5 / 5, \mathrm{Av} \cdot{ }^{12} / 2,{ }_{12}^{13}\right)$. Tonen var ved alt dette meget matadeholden. Ligeledes ved de tyske Afstemningsfester i Flensborg (H. ${ }^{14} /{ }^{3},{ }^{15}$ ). Minderne gav Indtryk af Liv og Vækst (H. ${ }^{15} / 6$ ). Paa Dybbol takker Statsministeren Befolkningen for dens Kærlighed og Trofasthed under Fremmedherredømmet og for de første 10 Aar (H. ${ }^{16}{ }_{6}$ ).

Den danske Stats Ulgifter ved Overtagelsen af Nordslesvig er bleven opgjort til 433 Mill. Kroner, men deraf el dog kun 150 Mill. direkte Udgifter (H. 3/4).

F ards l e $n$ over Griensen letteles en Del, særlig for Folk fra crmenseomraadet. Der aabnedes en ny Overgang cver Krusaa og indfortes Paskontrol i Togene mellem Padhorg og Flensborg. (H. $\left.{ }^{2 N} / 4\right)$. Et groft Brud paa Grenseordningen agtede tyske Kommunister at foretage den 15. Juni, idet de vilde drage over Gransen og marchere til Dybbøl for at forstyrre Festen, hvor Statsminister Stauning talte. Det blev dog forhindet. (H. ${ }^{16},{ }^{17 / 6}, \mathrm{Av} .{ }^{17} / 6$ ). Derimod lykkedes det dem senere at komme over og med et Møde paa dansk Grund at standse Landevejsfærdslen ved Krusaa. (H. 4/s).

Syd for Grænsen trykker den $ø$ k on $0 \mathrm{~m}$ is ke krise langt hatdere end Nord for den. Flensborg har isiel lidt ved Grænsedragningen. Den preussiske Stat sagte i sin Tid og bode paa det med $47 \frac{1}{2}$ Mill. Mk. og en Frihavn til mange Millioner. Men Pengene er borte, og Havnen er der ingen Brug for. $\left(\mathrm{H} .{ }^{19} / 2\right)$. I Foratret havde 12 af Byens Skibe maattet lagge op. (Av. ${ }^{12} / 4$ ). I Maj arbejdede Skibsværftet kun 3-4 Dage orn Ugen (Av. ${ }^{23}{ }_{5}$ ) og i September maatte det ny Vaerf, der i sin Tid sysselsatte 1000 Mand, lukke. (Av. ${ }^{20}{ }_{9}$ ). Paa det gamle var der den Gang endnu 800 Mand i Arbejde, men ${ }^{31} / 10$ blev dets sidste skib gjort færdig (Av. ${ }^{31} / 10$ ) og ved Nytaarstide maatte ogsaa det lukke. Allerede ved Lukningen i September var Antallet af Arbejdsløse steget til $3492 \bmod 1990$ Aaret for. (Av. ${ }^{20}$ ). Ved Aarets Slutning fik Byen dikteret en Fordobling af Ølskatten. (H. ${ }^{30} / 12$ ). Ogsaa paa Landet var Nøden stor. I Landkredsen steg Skatterne med 35-50 pCt. Nøden oges ved megen Mund- og Klovesyge. I Slesvig og Holsten var :266 Besætninger angrebne af den $\left(H .{ }^{24 / 8}\right)$. I Segeberg Kreds optraadte den i $80 \mathrm{pCt}$. af Kommunerne. (H. ${ }^{23} / \mathrm{s}$ ). 


\section{Nationalt Liv.}

a) Dansk Syd for Grir nsen.

Ved A a rsmødet i Flensborg $1 / 0$ meddeites det, at Stemneantallet i Byen var gauet ned fra 2900 til 1600 . Derimod var Medlemsantallet holdt. (Av. ${ }^{3} / \mathbf{B}, \mathrm{H} .{ }^{2 / 8}$ ). Denne Nedgang voldte, at der til La $\mathrm{L} d \mathrm{~d}$ a $\mathrm{g} \mathrm{s}$ valg e $\mathrm{t}$ ikke opstilledes Kandidater i Byen. $\left(H .{ }^{15} / \mathrm{H}\right)$. Alligevel afgaves der 1030 danske Stemmer i Byen, 433 i Landkredsen, 145 i Slesvig Kreds og 86 i Syd Tønder Kreds. (Av. ${ }^{17} / 4$, H. ${ }^{10} / \%$ ). Ved Mindet om Afstemningen faldt der trods den politiske Tilbagegang haabefulde Udtalelser om Danskhedens Bevarelse. (Av. ${ }^{14} \_{ }^{10} / 3$ ).

Slesvigsk $\mathrm{K}$ reditf ore $\mathrm{n}$ ing havde i Maj 47 Meillemmer og $5750 \mathrm{Mk}$. Andelskapital. Den havde sidste Aar ydet 20 Laan til $34,399 \mathrm{Mk}$. (Av. ${ }^{11} / \mathrm{s}, \mathrm{H} .{ }^{12} \mathrm{~s}$ ).

${ }^{1 N}$ s samledes der 5-600 Mennesker i Flensborg til et Made, hvor Knud Rasmussen talte. (H. 2" ${ }^{1}$ ).

Fl'a Bogsamlingen i "Flonsborghus» latutes $i 29: 30$ 46.059 Bøger ud mod 40,010 Aaret for. (Av. ${ }^{17} / \mathrm{s}$ ).

Midt i Maj fandt en Forhandling Sted om det dansk، Skolevasen. Fra dansk Side var man ikke tilfreds med, at man ikke kunde faa ot mele centlat beliggendr. Skolelokale og danskuddannede Iaprers og heholds det hidtidige Antal tyske Timer i Duhorgskolen. Skoleraad Dr. Siever's gar Rede for Regeringens Syn paa Sagen. Den danske Iareruddannelse anser dirn for ringere end den tyske. $\left(11,{ }^{15} / 5,{ }^{24} / 5,{ }^{2 H} / 5,{ }^{31} / 5\right.$, Av. $\left.{ }^{24} / 5\right)$. Den danske Skoleforening imstegaar dette. (Av. ${ }^{31} / 5$ ).

I Valsbøl indviedes et Fors a m l ing s h u s 11/10 (Av. ${ }^{2 k}$, 14/10). Det og andre lignende tynges af, at der i Tysklant maa betales Fjendomsskat ogsaa af Bygninger, dor tjener kulturelle Formaal, mens de her i Landet er skattefri. (Av. ${ }^{25} / 5$, H. ${ }^{27} / 5$ ).

Fra Begyndelsen af Juni er "Flensborg Avis" og "Der Schleswiger " slaaet sammen. (Av. ${ }^{3}, \mathrm{H},{ }^{2} / 6$ ).

Den 10. Maj fejrede Henrik Lassen og Hustru i Strukstrup Krondiamantbryllup. (Av. ${ }^{11} / \mathrm{s}, \mathrm{H},{ }^{12} / \mathrm{s}$ ).

b) Tysk S y d for Gransen.

Et unske orn et tysk Græn sefond paa det preus. siske Budget anbefales fra Slesvig og IIolsten. (H. 20/1). Pastor Joh. Tonnesen i Rendsborg hliver Professor verl det pæedagogiske Akademi i Altona. (H. ${ }^{18 / 2}$ ).

Ved tyske Vesterhavskyster blev der 1900-1927 ind- 
vundet 3595 ha $n$ y $t \mathrm{~L}$ a $\mathrm{n}$ d, deraf 4381 ved Slesvig og Holstens Kyster. Det har kostet 7,4 Mill. Mk., 1690 Mk. pr. ha. Der er nu bevilget yderligere $5,225,000 \mathrm{Mk}$. til dette Arbejde. For Fremtiden regnes der med $1200 \mathrm{Mk}$. pr. ha. (H. $4 /$ s). I Flensborg, Syd Tønder og Husum Kredse er der i de sidste 4 Aar dannet $470 \mathrm{n}$ y Ga a r de. (H. ${ }^{20} / \mathrm{s}$ ). Langs med Grænsen er der alene i Flensborg Landkreds oprettet $\times 5$ ny Landbohjem i de sidste Aar. (Av. ${ }^{20} / 5$ ).

Trods al Nød siettes der Millioner i det saakalite t y s k Hus i Flensborg, der indviedes sidst i september. (Av. ${ }^{24}, 9$, H. ${ }^{20} / 0$ ).

c) Tyski Nordslesvig.

Behandlingen af Tyskerne $i$ Nordslesvig anerkencles af fornuftigt tixnkende Tyskere som upaaklagelig. Dr. Leonhard skriver f. Eks., at Forholdene i Danmark er et ligefrem Mønstereksempel pua, hvordan de nationale Mindretal skal behandies (H. ${ }^{20}{ }^{\prime 3}$ ) og $\mathrm{i}$ den tyske Mindretalsavis "Deutsche Zeitung" betegnes den danske Mindletalsordning som "ligefrem eventyrlig". (H. ${ }^{31} / 3$ ). I enkelte Tilfælde kan den endog skyde over Maalet. Saaledes i Graasten, hvor den tyske Forpagter af Domænen efter Ordre fra Landbrugsministeren fik Forpagtningen forlænget med et Aar tvartimod hidtidig Praksis ogsaa overfor Danske. (H. ${ }^{8}$., ${ }^{12}$., ${ }^{14}$., ${ }^{18} / 3$ ). I Almindelighed har Tyskerne $\mathrm{i}$ alle Tilfalde ingen Grund til Klage. (1. ${ }^{31} / ;$ '.

Tyske $\mathrm{Krav}$ er alligevel ikke beskedne. Pastor schmidt forlanger i et Lovforslag, han har stillet, sarlige tyske Skolekommissioner, Eksamensret for højere tyske skoler og meget andet, der vilde begunstige Tyskerne frem for Danskerne. $\left(H,{ }^{27} / 2,{ }^{27} / 11\right)$. Dette Forslag blev dog afvist af Folketinget. (H. $\left.{ }^{3}{ }_{12}\right)$. I et enkelt Tilfælde afstedkom Mangel paa dansk Imødekommenhed en Del unødvendig Uro. Tyskerne i Haderslev onskede paa den tyske "Volkstrauertag" at faa ringet med Klokkerne i Frue Kirke. Dette modsatte Menighedsraadets danske Flertal sig, skønt Tyskerne allerede havde opnaaet en saadan Tilladelse andre Steder. (H. $\left.{ }^{17} / 2\right)$. Tyskerne ivarksatte derover larmende Protestmøder med store Ord og Trusler om Udtrædelse (H. ${ }^{18} / 2$ ). Under Magling af Biskop Ammundsen naaedes der Enighed om et Kvarters Ringning $i$ Tilslutning til den tyske Gudstjeneste den paagældende Dags Eftermiddag Kl. 5. (H. ${ }^{22}, 2$ ). Lignende blev det senere ordnet i Sønderborg. (H. \%/s). Paa Linje med utilbar- 
lige Krav stod det, at det tyske Ungdomshjem paa Galgebakken ved Aabenraa en Sondlag havde hejst ty sk Flag. (H. ${ }^{8}{ }_{10}$ ).

Tyskeme er ind by r des ikke enige om deres Holdning. Da de frisindede i Sonderborg ikke kunde komme til Orde i "Nordschleswigsche Zeitung", maatte de ty til "Hejmdal" for at faa deres Synspunkter frem. (H. ${ }^{11} / 1,{ }^{31} / 1$, 4., ${ }^{5},{ }^{22} / 2$ ) og Lorenz Christensen beskylder ligefrem den tyske Redaktor Kähler for at desorientere den offentlige Mening og at reducere den politiske Betydning af det tyske Blad til næsten intet (H. $\left.{ }^{17} / 8,{ }^{5},{ }^{8} .,{ }^{9} .,{ }^{11} .,{ }^{12} / 7\right)$.

Et stort Skaar voldte det Tyskerne, at $\mathrm{s} k$ ole indsam lingerne i Tyskland blev forbudt (II. ${ }^{14} / 7$ ).

Deres Organisationer vokser ellers godt. De har 38 Bogsamlinger nied 25,325 Bind, 4×86 Laanere og 75,490 Udlaan. 27 Privatskoler med 1114 Elever, Fremmedmenighederne (Schlesw. holst. Landeskirche) har i 20 Sogne afholdt 253 Gudstjenester, og de har 36 Ungdomsforeninger med 1600 Medlemmer $\left(\mathrm{H} .{ }^{30} / 1 \mathrm{w},{ }^{15} / 5\right)$. Deres Knivsbjergfest var efter Sigende besøgt af 6000 Mennesker (H. ${ }^{30} / 6$, Av. ${ }^{1}$ ). Pa deres Aarsmøde ${ }^{30} / 11$ havdede Pastor Schmidt, at de ikke onskede at isolere sig (H. ${ }^{2} /{ }_{12}$ ).

Om Skolerne meddeles, at der $10 / 1$ indviedes ny Lokale til l'rivatskolen i Broager $\left(H .{ }^{13}{ }_{11}\right)$. Privatskolerne i Aabenraa Amt havde i 19:2 203 Elever (H. ${ }^{23} / 1$ ). I Tønder Amt har Tyskerne Flertallet i 11 af de 19 blandede Skolekommissioner, der findes. I 3 af dem er der kun ét tysk Medlem. Der har $\mathrm{i}$ ingen af disse Skolekommissioner været Vanskeligheder (H. $\left.{ }^{23} / 2\right)$. De tyske Skoler har faaet 40 Radioapparater forseret $\left(\mathrm{H}^{6}{ }^{6}{ }^{3}\right)$. I Aabenraa oprettes der et tysk Privatgynınasium i Tilslutning til Privatskolen (H. ${ }^{17 / 4}$ ). 91 af de 351 Elever paa $\mathrm{H} ø \mathbf{j} \mathbf{s k o -}$ l e rne i Maarkær, Rendsborg, Lunde, Lirk og Berghof var fra Nordslesvig. Ligeledes Størsteparten af de 72 paa Højskolẹn i Tinglev (H. $\left.{ }^{28}{ }_{4}\right)$.

Frem medmenighederne har 1929 foruden 253 Gudstjenester i 20 Sogne holdt 197 Menighedsmøder i 24 Sogne, noget mere end i $1928\left(H .{ }^{28} / 1\right)$. En ny Fremmedmenighed dannes af 27 Familier i Hovslund og Østerløgum (H. 1/10). Tyskerne i Folkekirken ønsker egne Menighedsraad, Ansættelse af tyskuddannede Præster og Kirkebenyttelse af Præster i den "slesv.-holstenske Landskirke» uden Biskoppens Tilladelse $\left(H .{ }^{28} / 10\right)$. I Bedsted faar den tyske Menighed Ret til at bruge Kirken for 20 
Kr. pr. Gang (H. ${ }^{10} / 12$ ), og i Bov faar de et større Antal lløjmessegudstjenester (H. ${ }^{13}{ }^{\prime 12}$ ).

Vogelgesang ydede i 1929 r6 Laan til $476,230 \mathrm{Kr}$., og "Höfeverw'altung" resp. Kr'editanstalten flk tilskødet 12 Ejendomme til $663,500 \mathrm{Kr}$.

\section{d) Danski Nordslesvig.}

En god, sammentrængt Oversigt over det nationale Arbejde og vore Organisationers Styrke gives hvert Aar ved Aarsmødet, der holdtes den ${ }^{\circ}$. Sprogforeninge n, der ${ }^{10} / 10$ havde bestaaet i 50 Aar (H. ${ }^{8 / 10},{ }^{11}{ }_{10}$ ), havde 11,660 Medlemmer, 758 Tillidsmaend, $59,718 \mathrm{hr}$. Indtagt, s k ol ef orening en ca. 20,000 Medlemmer, $162,782 \mathrm{Kr}$. Indtægt. Den har hjulpet 293 fra Nord- og 70 fra Sydslesvig paa Skoler. Granseforeningen har ialt 43,000 Medlemmer, deraf ca. 5000 her i Nordslesvig. Dens Indtægt er $256,000 \mathrm{Kr}$. (H. $7 / 7$, Av. $\left.{ }^{3 / 3}\right)$. Haderslev Vesterants Grænseforening har 1526 Medlemmer, 150 flere end i Fjor $\left(\right.$ H. $\left.{ }^{10} / 3\right)$. Landevar nets Indtægt og Udgift balancerer med 109,740 Kr., dets status med 2,592,174 $\mathrm{Kr}$. (H. ${ }^{3}{ }_{3}$ ). Haderslev fsteramts Ungdomsforening har 15 Foreninger med $18(15$ Medlemmer under sig (220 Tilvækst) (H. ${ }^{27} / 10$ ). Til de danske Ungdomsforeninger hører her 6154 af deres 36,350 Medlemmer (II. $\% / 2$ ). Skoleforeningens Formand, H. Jefsen Christensen, mener, at den sønderjydske Ungdom nu er bedre end nogen sinde $(H$. $1 / 3$ ) og Johs. Juhl siger, at Ungdonimen hernede er i betydelig Fremgang (H. ${ }^{20} / 3$ ). Sonderjydsk Teaterforening bestaar af 39 Foreninger med ca. $7 C\left(00\right.$ Merllemmer (H. ${ }^{10} \%$ ).

Der er bygget ny Forsamlingshuse i Kværs (H. ${ }^{10} / 2$ ), Mjolden (Av. ${ }^{5} / 6$ og ${ }^{8} / 6$ ) og Løjt (H. ${ }^{12} / 12,{ }^{15} / 12$ ). Højskolehjemmet i Haderslev havde $12,962 \mathrm{Kr}$. Indtægt og $2900 \mathrm{Kr}$. Underskud (H. $\left.{ }^{6} / \mathrm{s}\right)$, Tonderhus er nu $\mathrm{i}$ god Udvikling (H. ${ }^{2 y} / 3$ ).

Hoptrup H øjs k ol e har i 10 Aar haft ca. 1600 Elever. Den mangler endnu $50,000 \mathrm{Kr}$. for at være akonomisk sikret $\left(\right.$ H. $\left.{ }^{17} / 2\right)$.

I Januar foreslog Redaktør Valdemar Petersen i Sorø, at indrette Forsamlingshusene til $\mathrm{V}$ andreherberger om Sommeren (H. ${ }^{24}$ ). Tanken vandt Tilslutning (H. ${ }^{3 / 2}$ ). Hernede erklærede ca. 10 Forsamlingshuse sig villig til at modtage rejsende Ungdom (H. $\left.{ }^{14} / \mathrm{s}\right)$. Antallet voksede senere til 15, der tilsammen kunde modtage 370 Gæster i 
Tiden fra $1 / 7$ - ${ }^{11} / 4$ (H. ${ }^{17}$ e, Av. ${ }^{20 / 8}$ ). Disse Rejsehjem blev i Sommerens Løb brugt af 391 (H. ${ }^{5 / 12}$, Av. $^{17} / 12$ ).

Den danske $\mathrm{B} ø \mathrm{r} \mathrm{n}$ eh a ve i Tønder havde et gennernsnitligt Besøg af $51($ H. $4 / 2$ ).

Sonderjydsk I d r $\mathfrak{r}$ t $\mathrm{s}$ f or en ing havde i $1929 \quad 2150$ Fremgang og har nu 9601 Medlemmer $\left(\right.$ H. $\left.{ }^{18 / 1}\right)$. Den bevarer. Fællesskabet med Skytterne (H. $\left.{ }^{10} / \mathrm{s}\right)$. I Maj var der stort Gymnastik- og Idrætsstapne for 2000 Skoleelever i Sønderborg.

Danmarks Lærerforening onskede at yde $\mathrm{S}$ tøt te til det nationale Arbejde hernede ved en aarlig Indsamling i Skolerne den 10. Februar, men Ministeriet vilde ikke tillade det. Den vedtog derfor at arbejde for Tilslutning til de nationale Foreninger (1I. $1 / 2$ ). Et clansk Egtepar i Amerika har testamenteret de nationale Foreninger i Sønderjylland 6000 Dollars (H. ${ }^{10} / 10$ ).

Fra Haderslev Frue Kirke onskede man at udse $n$ d e Afstemningsgudstjenesten, men Radioraadet nægtede $\operatorname{det}\left(\mathrm{H} .{ }^{\mathrm{a}}{ }_{2}\right)$.

I en $\mathrm{R}$ e j s e til København deltog 60) fra hvert Amt (2000 fra Haderslev Amt havde meldt sig til den) (H. ${ }^{17} / \mathrm{s}$, $\%,{ }^{13} / 9$ ). I en Udflugt som Historisk Samfund for Sønderjylland iværksatte til Slesvig for at se Hedebyudgravningerne, deltog 200. (H. $\% / 10$ ).

I Begyndelsen af Juni aflagde nordiske Journalister et Besøg i Aabenraa, paa Vestkysten og paa Dybbol. (II. 2/6, 1/6). Et Par Uger senere besøgte Dansk-Amerikanere Aabenraa, Dybbøl og Als. (H. $\left.{ }^{18}{ }^{\prime}{ }^{6}\right)$. Tønder gastedes i F jor af 15,000 Turister. (Av. ${ }^{25} / 4$ ).

I Maj aflagde Kongen sit aarlige Besøg her nede. (II. ${ }^{22}$., ${ }^{24} / 5$, Av. ${ }^{23} / 5$ ).

Paa Grundlovsdagen afsloredes en Mind esten paa Urnehoved. (H. $6 / 6$ ). I Aabenraa rejstes en Mindesten for Fr. Fischer i Folkehjems Have (H. ${ }^{25} / 6,{ }^{26} / 0$ ) og i Hammelev en for Hans Nissen. (H. ${ }^{20} / \mathrm{g}$ ).

I Foraaret begyndte den nye store $\mathrm{S}$ ønderjyllands $\mathrm{H}$ is torie i 5 Bind at udkomme. (H. ${ }^{1 / 3}$ ). I August holdtes Hjemstavnskursus paa Rønshoved Højskole (H. $\left.{ }^{2} / \mathrm{s}\right)$ og i September holdt »Historisk Samfund for Sønderjylland" sit Aarsmode i Tønder. Det har 681 Medlemmer. (Av. ${ }^{23 / 9}$, H. ${ }^{22} / 0$ ). Historisk Samfund for Als og Sundeved har 153 Medlemmer og $9 \times 4$ Kr. Indtagt (H. ${ }^{25 / 3}$, Av. 20/3). 


\section{Politik.}

Gaardejer Johan Nissen i Strandelhjørn blev Stedfortræder for Folketingsmand Holger Andersen, der rejste til Konstantinopel som Folkeforbundets Kommissær. (H. 1/3). Landstingsmand Holger Fink nedlagde sit Mandat, hvorefter Kloppenborg Skrumsager blev Landstingsmand. (H. $\%$ \%).

\section{Samfundsforhold.}

Ved Folketallingen i 1930 viste det sig, at Fol ket a llet $\mathrm{i}$ hele Landsdelen var steget 1228 siden 1925 . Det udgør nu 177,661. (H. 8/12). Af Byerne havde Aabenraa 165 Fremgang, nu 8,817. I de 5 Aar var der flyttet ca. 300 flere til Udlandet end der var kommen derfra. (H. $\% / 12$ ). Haderslev havde 150 Fremgang, nu 14,476. Sønderborg 369 Fremgang, nu 10,823. Tønder havde derimod 112 Tilbagegang, nu 5,754. (H. $8 / 12$ ). Børneantallet i Skolerne begynder nu ogsaa at stige. (H. ${ }^{15} / 11$ ). Af de 812 Personer, der i Fjor fik Indfødsret i Danmark, boede 87 i Sønderjylland (H. ${ }^{14 / 11}$ ).

Ved Nytaar var der 250 Ansøgere til $70-80$ ny $\mathrm{H}$ u sm a nd sbrug i Sønderjylland. (H. $3 / 1$, Av. ${ }^{14} / 1$ ). Paa Rumohrsgaard kunde der oprettes 21 nye Brug, (H. ${ }^{\text {1日/2) }}$ ) paa Graasten Herregaard 9, (H. ${ }^{17} / \mathrm{s}$ ) paa Adelvad 11, (H. ${ }^{1 \%} / \mathrm{s}$ ) paa Hornsgaard i Fol Sogn 7, (H. $8 / 4$ ). I Bjerndrup er der dannet en helt ny By, flks og færdig (H. $\left.{ }^{19} / \theta\right)$ de første 4 Brug er solgt. (H. 1/10). I Aarets Løb dannede Jordlovsudvalget 35 ny Ejendomme i Tønder Amt (H. $\left.{ }^{28} / 10\right)$, hvor der siden Genforeningen er udlagt 180 ny Brug og 20 Tillægsparceller. (H. ${ }^{19} / 11$ ). I det hele er der i Sønderjylland udstykket ca. 1200 ha til 114 ny Brug i ${ }^{1028} / 30$ (H. $2 / 5$ ) og Staten har 120 Brug under Forberedelse her nede. (H. $\left.{ }^{10} / \mathrm{s}\right)$. Af 491 Ansøgere til Statsjord er 110 fra Nordslesvig. (H. 11/12). Ved Siden af Jordlovsudvalget virker Udstykningsforeningen, der ialt har oprettet 70 Ejendomme. $\left(\mathrm{H} .{ }^{28} / \mathrm{s}\right)$.

Udstyknings $p r i n c$ i $p$ e t er stadig under Drøftelse. Paa et Husmandskursus i Aabenraa var de fleste for Statsfæste, mens Lorenzen, Rørkær, pegede paa dets nationalt uheldige Side $\left(\mathrm{H}^{3} / 2\right)$ og $\mathrm{H}$. Jefsen Christensen i Landstinget talte imod det. (H. \%). De samvirkende sønderjydske Husmandsforeninger kræver paa et Møde i Aabenraa Præstegaardsjorden udstykket. (H. ${ }^{23} / 8$ ).

Den første Havek ol oni ved Haderslev, Borgme- 
sterkobbelen, har kostet $34,000 \mathrm{Kr}$, deraf resterer endnu 13,000. (H. ${ }^{24} / 2$ ).

Den alsiske Brand forsikring for Bygninger har 303,558 Kr. Overskudsreserve og et Reservefond paa 71,333 Kr. Den har 3064 Medlemmer med over 58 Mill. Kr. Forsikringssum. (H. $\left.{ }^{27} / 2\right)$. Brandskaderne paa Landet i Nordslesvig har fra 1920-29 udgjort ca. 15 Mill. Kr. De er især vokset siden 1925. (Av. $/ 7$ ). Den nordslesvigske, nordøstslesvigske og Lø Herreds Brandforsikringer er derved kommen i Vanskeligheder og maatte slaas sammen. ( $H$. $\left.18 / 12,{ }^{20}, 12\right)$.

Haderslev By eftergav i Maj al uforskyldt Fat i gh j æl p. $\left(\right.$ H. $\left.{ }^{7} / \mathrm{s}\right)$.

Aabenraa By agter at danne en Badestrand ved Sønderchausse i Lighed med den i Eckernførde. (H. $\%$ ).

A lderdomshjemmet "Alderstrøst" i Aabenraa har virket i 50 Aar. (H. ${ }^{10} / 11$ ).

Den nordsl. Kvindeforening, der driver et $\mathrm{H} v$ ileh jem og flere $B ø r n e h j e m$, havde et godt Arbejdsaar og et tilfredsstillende Regnskab. (H. $\left.{ }^{27} / 6\right)$.

A nıts s gehuset i Haderslev har 123 Senge, i Gram 74 . $\left(\right.$ H. $\left.{ }^{17} / 7\right)$. Ved Aabenraa Sygehus tages en Epidemibygning i Brug. (H. ${ }^{17} / 12$ ). Der er 77,039 Medlemmer i $105 \mathrm{Sygekasser}$. (H. ${ }^{10 / 7}$ ). Helseh jemmet har i 10 Aar huset 2760 Børn. (H. 1/0). Tuberkulosen er endnu slem her. (H. ${ }^{22} / 8$ ).

I Tønder Amt er Fød se is t a lle t paa Landet 21,2 , i Byerne 21,0 pro mille, Dødstallet henholdsvis 8,3 og 8,0. Tønder Amts Sygehus har 90 Senge, Logumkloster 20, Tuberkulose angaves som Dødsaarsag 7 Gange fra Byerne og 12 Gange fra Landet. Tyfus er bleven en sjælden Sygdom. (Ber. 1930). I Haderslev Amt var Fødselstallet i Byerne 18,9 , paa Landet 18,2 pro mille, Dødstallet henholdsvis 12,6 og 8,8. (Ber. 1930).

\section{Erhverv og Okonomi.}

a) L a nd brug.

Den $\mathrm{O} \mathrm{ml}$ I g n ing a f D riften, der maatte blive en Folge af Grænseflytningen, er vel nok i Almindelighed vidt fremskreden, men ikke allevegne gennemført, mindst vel nok paa Vestkysten. Paa Landboforeningens Generalforsamling i Bredebro ${ }^{18} /$, hævdede Gaardejer Hans Beyer, Aasgaard, stattet af flere Talere, at det havde set bedre 
ud der paa Egnen, hvis der havde varet drevet typisk dansk Landbrug i større Udstrækning, end Tilfaldet er. (H. ${ }^{20} / 1$ ). I Senderjylland som Helhed er Græsarealet endnu mere end $11 \mathrm{pCt}$. over Landsgennemsnittet. (H. ${ }^{31 / 1}$ ). Denne Omlægning kræver mange Steder bl. a. S a mling a f Ejendommene ved Magelæg. Indtil Nytaar 1930 var denne foretaget eller foreslaaet med 6564 ha, og der var oprettet 121 nye Brug ved Udstykning af Udmarker fra Gaarde. (H. $\left.{ }^{17} / 1\right)$. Følgende Tal giver et Indtryk af, hvor vidt Omlagningen er fremskreden; Roearealet er siden 1920 vokset med ca. 50 pCt., Korarealet med ca. 11,000 ha, Koantallet med over 27,000), Svineantallet fra 108,000 til 271,000. Mælkemængden er 50 pCt. over 1913. (H. ${ }^{10} / 2$ ). Der tegnedes i 1930 godt 600 Tønder Land til Dyrkning af Sukkerroer. (H. ${ }^{23} / 4$ ).

I 1924 avledes der F r $\varnothing$ paa 150-200 ha, og i 1930 oprettedes et Frotorreri i Sønderborg (II. ${ }^{20 / 2} / 2$ ).

Plantning tager stærkt til, især af Rødgran ( $\mathrm{H}$. 28/2). Alene i Nørre Rangstrup Herred flk 193 Medlemmer af Plantningsforeningen i 1929 udleveret 73,840 Naaletræsplanter og 59,861 Løvtræer (H. ${ }^{27 / z}$ ), og Plantningsselskabet "Sønderjylland" har siden 1920 udleveret ca. 15 Millioner Planter (Av. $\left.{ }^{28} / 4\right)$.

Fæsted Planteselskab har i 25) Aar omdannet 200 Tonder Land Hedo til Skov (II. ${ }^{1 H} / 7$ ), Sonderborg og Aabellrad Amters smauskovsforening har fadet $2 \tau$ ny Medlemmer medl 1)4 ha, mens 8 med 27 ha har meldt sig ud. Den har nu 240 Medlemmer med 1167 ha, og Interessen for Skovenes rigtige Behandling el stigende. (II. ${ }^{27} / 6$ ).

Et Mergling s selskab dannedes for Vojens og Omegn (H. $9 / 1$ ), og der tegnedes $75,0100 \mathrm{~m}^{3}$ til 11 Byer (H. $\left.{ }^{10} / 1\right)$. I Skar rbæk dannedes et lignende med ca. 100,000 $\mathrm{m}^{3}$ (Av. ${ }^{23} / 10$ ).

Kultivering af vandsyge Arealer skrider godt fremad. Afvandingen af Marsken ved Tønder er næsten færdig. Den bliver imidlertid dyrere end beregnet og opføres paa Finansloven med 1,1 Mill. Merudgift (H. $\left.{ }^{1 *}{ }_{3}\right)$. De tyske Grundejere, hvis Land lider under de danske Digebygninger, har man budt 140,000 Mk., hvad de ikke el tilfreds med (H. $\left.{ }^{5} / 4\right)$. Senere besindede de sig dog (Av. ${ }^{3} / 7$ ). Der er under dette Arbejde bygget $80 \mathrm{~km}$ Diger, anlagt $200 \mathrm{~km}$ Kanaler og gravet $10,10 \mathrm{~km}$ Grøfter. Derved beredes 10,000 ha for Ploven (H. 1/s). Der skal endnu graves 4 Afvandingskanaler i Gammel og 1 i Ny Frederiks- 
kog paa tilsammen $6 \mathrm{~km}$ (Av. ${ }^{11 / 12}$ ). Engene ved Sejersbækken giver nu 4 Gange saa meget Hø som før Afvandingen (Av. ${ }^{7} / 8$ ). Desværre begynder de afvandede Enge ved Tønder nu at plages af Mus (Av. $\left.{ }^{16} / 7\right)$. Løbeorm gør i Ballum og Skærbæk Enge Skade for ca. 100,000 Kr. (H. $3 / 6$, Av. $\left.{ }^{4} / 6\right)$. Under Drøftelse staar endnu en Plan om Regulering af Bredeaa nedenfor Løgumkloster. Den vilde komme 3000 ha til gode. Faldet er her $9,5 \mathrm{~m}$ paa $30 \mathrm{~km}$ (Av. ${ }^{4}{ }^{\prime}$ ).

I $\mathrm{Kvægbruget} \mathrm{lægger} \mathrm{man} \mathrm{især} \mathrm{Mærke} \mathrm{til} \mathrm{K} \mathrm{o-}$ a n talle t. Det er fra ${ }^{28 / 29}{ }^{29} / 30$ steget med $2 \%$. Mælkemængden er steget paa saa godt som alle Mejerier, paa en Del med indtil $12 \%$. I Haderslev Amt er $50 \%$ af Køerne under Kontrol, i Sønderborg Amt $40 \%$, i Aabenraa Amt ca. $30 \%$, men i Tønder Amt kun $13-14 \%$ (H. ${ }^{13} / 3$ ). Den aarlige Mælkemængde til Nordslesvigs 142 Mejerier steg fra 139 Mill. $k g$ i 1921 til 236 Mill. i 1924 og 280 Mill. i 1928. Koantallet, der var sunket fra 113,359 i 1913 til 82,770 i 1920 , steg til 110,264 ,i 1929 (Av. ${ }^{22} /$, L. S. 110f). Siden den første danske Tælling er Koantallet steget $30 \%$. Smørudbyttet pr. Ko er.ligeledes steget, i 1929 med $7,7 \mathrm{~kg}$ pr. Ko. Det er nu gennemsnitlig $138,8 \mathrm{~kg}$. Der arbejdes nu i 96 Kontrolforeninger med ca. 35,358 Køer. I 1928 var der 88 Foreninger med 31,756 Køer (L. S. 1. f.).

Sønderjydsk Smør staar i K valite t godt. Ved Laboratoriets Bedømmelser kom det kun til at ligge 0,05 Points under Landsgennemsnittet $\bmod 0,1$ Aaret før. Kvalitetsbetaling for Mælken gaar da ogsaa jævnt fremad (L. S. 28).

Kvægavlsforeningen under "Fællesledelsen for Avlen

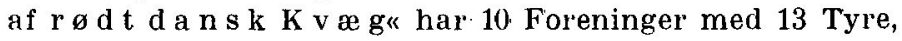
250 Medlemmer med $2050 \mathrm{Køer}$, hvoraf 1659 er kontrolleret (L. S. 52). . De 10 højest ydende Besætninger har i 1929 givet $30 \mathrm{~kg}$ Smør mere pr. Ko end i 1928 og de 10 højest ydende Køer $38 \mathrm{~kg}$ mere end i 1928. Gennemsnitlig gav Køerne $3675 \mathrm{~kg}$ Mælk med 3,64 \%. Fedt og $149 \mathrm{~kg}$ Smør (II. ${ }^{6} / 2$, L. S. 73 f.). Jes Andersen i Himmark's 5,7 Aarskøer har givet $6661 \mathrm{~kg}$ Mælk, 4,8 \% Fedt og $304 \mathrm{~kg}$ Smør. Det er »den højeste Gennemsnitsydelse af en Besætning her i Landet, maaske i hele Verden" (L. S. 73).

Korthornsavlen har 59 Kontrolforeninger med 1553 Besætninger og 23,606 Køer. De har i Gennemsnit ydet $3469 \mathrm{~kg}$ Mælk, 3,62 \% Fedt og 139,8 kg Smør pr. Ko. Fremgangen fra det foregaaende Aar er 7,1 kg Smør pr. Ko (HI. $\% / 12$ ). 
I Hesteavlen er der sket store Fremskridt siden Genforeningen (H. $4 / 3$ ).

Blandt Husmændene i Hjerndrup Sogn hlev en Kontrolforening efter ny Methode sat i Værk (H. 15/2).

Mejerierne holder gerne deres Generalforsamlinger og aflægger deres Beretninger mod Slutningen af Aaret (H. ${ }^{3}$., $4,{ }^{5}$., ${ }^{7},{ }^{14},{ }^{17} / 11$ ). Ved den Tid fremkommer ogsaa Beretningerne fra mange Kontrolforeninger ( $\mathrm{H}$. $., 5 / 11)$. Af 74 indberettende Mejerier nar nu 58 Fedtafregning (L. S. 381). En Hemsko for Fremskridtet er Fællesmejerierne. (L. S. 652).

$\mathrm{S} m ø \mathrm{r}$ a $\mathrm{lg}$ et sker jo for en væsentlig Del gennem Smøreksportforeningerne, af hvilke den i Haderslev omdannedes til et Aktieselskab (H. $\left.{ }^{2} / 9\right)$, den i Vojens har et Overskud af 1/4 Mill. og er i stadig Vækst. $\left(\right.$ H. $\left.{ }^{25} / 10\right)$. Den var den første, der indførte ugentlige Smørbedømmelser, nemlig straks efter Dannelsen i 1905, mens man Norden Aa først meget senere gik over til det. Her er nu $80 \mathrm{pCt}$. af Mejerierne sammensluttet i Salgsforeninger, mod kun 40 pCt. i det øvrige Land. (L. S. 140). Sønderjydske Landmænds Eksportforening i Sønderborg har 43 Mejerier. Dens Omsætning er steget med 9,7 pCt.

En A f $\mathrm{s} \not$ r ring af Aabenraa og Tønder Amter paa Grund af Mund- og Klovesyge voldte umaadelig Ulempe paa en Tid, da der alene paa Vestkysten gik 45000 eksportfærdige Kreaturer, som man havde ventet at tjene $90-100 \mathrm{Kr}$. paa pr. Styk, men som nu ikke var til at afsætte. $\left(\right.$ H. $\left.{ }^{26} / \mathrm{s}\right)$. De Foranstaltninger, der fra Statens Side sattes i Værk for at bøde paa Ulempen, vandt kun ringe Bifald og Paaskønnelse. (II. ${ }^{15}$., ${ }^{21}$., ${ }^{23}$., ${ }^{25} / 8,{ }^{10} .,{ }^{18},{ }^{27}, 8$, $\left.{ }^{23} / 10\right)$, (Av. $\left.{ }^{16} / \mathrm{s},{ }^{11} / 0,{ }^{18} / 0,9 / 10\right)$. Ogsaa Eksportmarkedet i $\mathrm{Ha}$ derslev gik stærkt tilbage i November og December $(\mathrm{H}$. ${ }^{13 / 12}$ ). I 1929 gav Staldene $10 \%$ Dividende (H. $\%$ ).

Desvarre volder $0 \mathrm{ks}$ e b remsen endnu alt for stor Skade hernede. I 1929 var $23 \% \%$ af Huderne vernede, i Nørrejylland $6 \%$ og paa Øerne endog kun $1 / 2 \%$ (L. S. 182).

Af S vin fandtes der ${ }^{15} / 729 \quad 47,267$ i Tonder Amt, ${ }^{15} / 730$ derimod 71,196 (Av. 14/10). For hele Nordslesvig var Antallene følgende:

Amt

Tonder

Haderslev

Aabenraa

Sønderborg
$15 / 729$

47,000

98,000

56,000

70,000
$15 / 730$

71,000

137,000

78,000

91,000
Tilvækst

$51 \%$

$40 \%$

$40 \%$

$28 \%$ 
Gennemsnitstilvæksten for hele Landet var $36 \%$. Tonder Amts er den største i hele Landet (Av. ${ }^{28} / 12$ ). Efter en Regnskabsførings Opgørelse gav Svinene ${ }^{1020} /$ so gennemsnitlig $15 \mathrm{Kr}$. Overskud (H. ${ }^{1 / 1}$ ).

Paa Slagterierne slagtedes følgende Antal Svin i 1929: Tønder 17,926 (H. \%, Av. /1), Sønderborg 62,658 (H. ${ }^{9} 1,{ }^{20} / 2$ ), Aabenraa 61,653 (H. ${ }^{15} / 2$ ), Rødding 56,277 (H. ${ }^{21} / 2$ ), Graasten 54,966 (H. $\left.{ }^{22} / 2\right)$, Vojens 22,889 (H. $\left.{ }^{28} / 2\right)$, Skærbak 21,338 (H. $\left.{ }^{3} / 4\right)$, Slagteriet i Haderslev skal udvides (H. ${ }^{B}{ }_{11}$ ). I Løbet af 1930) slagtede Sønderborg Slagteri 17,0ro Svin flere end Aaret for (H. ${ }^{31} / \mathbf{1 2}$ ).

Fra de forskellige Landboforeningers $R$ eg $\mathbf{n s k a b s -}$ for e $n$ inger meddeles:

Haderslev Amt: Den omifatter 33 Landbrug af 57,7 ha i Gennemsnit. Forrentningsprocenten i $1929-30$ var i bedste Tredjedel $9,5 \%$, i midterste $5,6 \%$, i daarligste $3,2 \%$. Den alsiske $7,2 \%$, den nordslesvigske $6,3 \%$. Aabenraa Amt: 67 Ejendomme, Gennemsn. 5,0\% (Ber. H. ${ }^{11} / 3$, $\left.{ }^{12} / 3,{ }^{1} 11,1 / 11,5 / 11,{ }^{10} / 11\right)$.

Ved Fælleslandbof oreningens Generalforsamling ${ }^{27} / 2$. gaves en Del Oplysninger om Landbrugets Stilling $\left(\mathrm{H}^{2}{ }^{28} / 2\right.$ ). Den alsiske Landboforening fejrede 75 Aarsjubilæum. Træk af dens Historie fremdroges (H. ${ }^{20}{ }_{3}$ ). Als Nørreherreds Landboforening blev 50 Aar (H. ${ }^{12} / 3,14 / 3$ ). Fælleslandboforeningen indsætter en ny Konsulent for Grænseegnene (H. ${ }^{28} / 6$ ). I et landbrugsfagligt Kursus $i$ Graasten deltog 150 Lærere (H. ${ }^{1 / 8}$ ).

b) Industri og Ha andvar.

Sonderjyllands starste industrielle Anlæg, $\quad \mathbf{~} \varnothing \mathbf{j}$ spanding s værket i Aabenraa har i 1929 leveret 10,2 Millioner kWh (H. $8 / 1$ ). Dets Anlægskapital er nu efter Afskrivning af $2,217,000 \mathrm{Kr}$. nede paa $1,397,000 \mathrm{Kr}$. I 29-30 er der tilsluttet 11 ny Transformatorstationer. Forbruget stiger, mest til Landbrugskraft, og Priserne nedsættes stærkt. Generalfors. ${ }^{30} / \mathrm{s}$ (H. $\left.{ }^{31} / \mathrm{s}\right)$. I Sønderborg og Aabenraa Amter steg Strømsalget med 20\%, og Prisen nedsattes $(H .3 / 6)$. I Midtsønderjylland er det steget med $18 \%$, mest med Kraft til Landbruget. Ogsaa her nedsattes Priserne (H. $3 / 6$ ). Det samme skete paa Vestkysten (H. 11/s, Av. ${ }^{15}$ s). Paa Haderslev Næs steg Forbruget med 24\% (33 til Landbrugskraft) (H. $\left.{ }^{21} / 7\right)$. Nedlægningen af Forbindelseskablet Aabenraa-Flensborg paabegyndtes ved Aabenraa ${ }^{3}{ }_{1}$. (H. $1 / 1$ ). Forbindelsen tilvejebragtes i Maj og virker heldigt (H. ${ }^{25 / 4}$ ). 
Tonder A k ti e bryggeri giver 5\%. Det har 14,467 Kr. Overskud (Av. ${ }^{23} / 3$ ).

17 sammensluttede $\mathrm{T}$ e g lv $2 \mathrm{r}$ k e $\mathrm{r}$ ved Egernsund og Nybølnor er nu oppe paa en Produktion af 50-60 Millioner Sten (Av. \%)

\section{c) Handel og Skibsfart.}

I Havnene indgik i 29-30 $10,899 \mathrm{~S} \mathrm{k}$ i be, deraf 4,813 i fri Trafik (H. $\left.{ }^{11} / 6\right)$. I Rutefart indgik i $28-29$ i Sønderborg 2,184, Graasten 1,684, Aabenraa 801, Haderslev 2,061 Skibe paa henholdsvis $168,598,91,961,56,724$ og 113,116 Reg. Tons. I fri Fart indgik i Sønderborg 1229, Graasten 1192, Aabenraa 803 og Haderslev 904 Skibe paa henholdsvis 92,274, $37,871,87,964$ og 75,701 Reg.-Tons (H. $8 / 1,18 / 1,11 / 3)$. Der er i samtlige sønderjydske Havne $29-30$ losset 504,464 og ladet 154,674 Tons Gods, heraf henholdsvis 459,818 og 123,455 Tons i fri Trafik $\left(\mathrm{H} .{ }^{20} / \mathrm{\theta}\right)$. I Haderslev forberedes et nyt Havneanlæg ved Sydsiden af Fjorden (H. $\%$ ). Haderslev Havn havde 29-30 200,300 Kr. Indtagt. Den gav 55,000 Kr. Overskud (H. $\left.{ }^{15} / 8\right)$.

Fra Aabenraa var der ved Nytaarstide stor Sildef a ng s t $\left(\right.$ H. $\left.{ }^{8} / 1\right)$.

d) Pengevæsen.

Af B a nke rne har Folkebanken for Als og Sundeved haft $93,365 \mathrm{Kr}$. Overskud. Den giver $6 \%$ Dividende og har haft 298,764,069 Omsætning (H. ${ }^{13} / 2,{ }^{24} / 2$ ). Haderslev Bank har ca. 70,000 Kr. større Overskud end i Fjor, nemlig $323,739 \mathrm{Kr}$. Dens Omsætning er vokset og den giver $10 \%$ Dividende $\left(\mathrm{H} .{ }^{10 / 3}, 15 / 3\right)$. Folkebanken i Aabenraa har haft 125,332 Kr. Nettooverskud. Ogsaa dens Omsætning er vokset $\left(H .{ }^{15} / 3\right)$. Tønder Landmandsbank har siden Rekonstruktionen anvendt $\mathbf{9 4 , 1 7 2} \mathrm{Kr}$. til Dækning af Goodwillkontoen og til ekstra Godtgørelse til de gamle Aktionærer. Den har henlagt $27,137 \mathrm{Kr}$. til Reservefond $\left(\mathrm{H}\right.$. $\left.{ }^{17} / \mathrm{s}\right)$.

Et Par Sparekasser, nemlig Tønder og Sønderborg mindedes, at det var 110 Aar siden de oprettedes (H. ${ }^{27} / 2,28 / 2$ ). I Frøs og Kalvslund Herreders Sparekasse er Sparernes Tilgodehavende steget fra $640,640 \mathrm{Kr}$. i $20-21$ til 2,305,736 Kr. i $29-30$. Samtidig er Omsætningen steget fra 3,551,014 til 39,779,263 Kr. (H. \%/s). Antallet af Indskydere i Sparekassen for Haderslev Byes Omegn er fra 3454 i 1923 steget til 7075 i 1930 (H. ${ }^{3 / 7}$ ).

Sparekassen for Aabenraa By og Omegns Indskud er vokset med 256,000 sidste Aar og er nu 6,418,795 (H. ${ }^{28 / 6}$ ). 
t e neds t t els e af gennemgaaende $1 / 2 \%$ (H. $\left.{ }^{8 / 3},{ }^{21} / \mathrm{s}\right)$.

Hy ot ek la a nefonden, der skulde standse til ${ }^{31} /$ s. modtog i Løbet af 10 Dage 150 ny Laaneandragender (H. ${ }^{7 / 3}$ ). Den har sidste Aar ydet 583 Laan til $2 \frac{1 / 4}{4}$ Mill. Kr., ialt nu 2377 Laan til 141/2 Million (H. ${ }^{13} / 10,{ }^{14} / 10$ ).

Sønderjyllands $\mathrm{Kreditf}$ orening har i sidste Regnskabsaar udlaant over 8,9 Mill. Kr. (H. ${ }^{15} / 10$ ).

Sønderjydsk Fond har i 1929 anvendt 241,252 Kr., ialt nu 11 Millioner (H. ${ }^{10} / \mathrm{s}$ ).
e) Sa m k ve m.

$\mathrm{V}$ e je ne er jo nu igen ved at blive de vigtigste Færdselsaarer. Efter den Plan, der efter Genforeningen lagdes for Udbedringen af de frygteligt ødelagte Veje i Sønderjylland, skulde der istandsættes $406,4 \mathrm{~km}$ gammel Landevej, de saakaldte Provinsveje, og udbygges 428,1 km ny Landevej. Allerede dermed vilde Vejnettet her i Tæthed svare til det paa Øerne. Imidlertid er der senere kommen ny Planer til. Af de færdige Veje var 1/4. 29 i Haderslev Amt $13,52 \%$ tjæret, i Tønder Amt 2,86\% brolagt, i Sønderborg Amt $3,47 \%$ asfaltbetoneret, i Aabenraa Amt $0,83 \%$ brolagt (H. ${ }^{2} / 7$ ). I Juni 1930 var der i Haderslev Amt tjæret og asfalteret $37,5 \mathrm{~km}\left(\right.$ H. $\left.{ }^{18} / \mathrm{e}\right)$, og i Sønderborg Amt var man nu i Færd med at belagge de stærkt befærdede Strækninger med Dammann Asfalt i Stedet for før med Asfaltbeton. (H. ${ }^{26} / 8$ ). Der har man i 10 Aar bygget $70 \mathrm{~km}$ ny Vej. (Av. ${ }^{11} / \mathrm{a}$ ). I Aabenraa Amt skal der bygges $25 \mathrm{~km}$ ny Landevej $\left(\mathrm{H} .{ }^{13} / 11\right)$ efter at Kystvejen er taget i Brug (H. $\left.{ }^{2} / 1\right)$ og Vejen Lundsbjerg-Tinglev er bleven færdig. (H. $/ / 11$ ). I Haderslev Amt er der Plan om 22 ny Vejarbejder (H. ${ }^{18} / 11$ ) deriblandt 23-24 km paa Haderslev Nas (H. ${ }^{10 / 3}$ ). Alt imens er Planen om en Skraavej Aabenraa-Esbjerg dukket op. (H. ${ }^{20} \%$ ). Alt dette koster mange Penge.

Af $\mathrm{Vej}$ f onde $\mathrm{n}$ er der bevilget 2,7 Millioner til det (H. $\left.{ }^{20} / \%,{ }^{22} / 0\right)$, men Vejvæsenet faar ogsaa en Udgift i Haderslev Amt af $1,445,000 \mathrm{Kr}$. (II. ${ }^{10 / 11}$ ). $1^{27} / 28$ var det 732,225 Kr. (H. 1/2), i Tønder Amt af 535,730 Kr. (H. 1/12), og Sognekommunerne i Haderslev Amt søger Tilskud af over 2 Mill. af Vejfonden til Vejarbejder. (H. ${ }^{20} / 12$ ).

A $m \mathrm{ts}$ banerne gaar det stadig daarligt med. De haderslevske giver 185,000 Kr. Underskud, Aarøsundbilen12/s). Haderslev Bibliotek har 12,400 Bind, 44,643 Udlaan, 2947 Laanere, 406 Medlemmer (H. ${ }^{14} / \mathrm{s}$ ).

I Kolding onskede man at anbringe $\mathrm{L}$ a $\mathrm{nds}$ a rkive t i Slotsruinen (H. $\left.{ }^{18} / 4\right)$. 
derimod $3000 \mathrm{Kr}$. Overskud (H. $\left.{ }^{30} / \mathrm{s}\right)$, og de alsiske giver 22,900 Kr. Underskud. (H. ${ }^{10} / \mathrm{l}$ ).

A a røsund f r gen har i 1929 udført 1368 ordinære Ture mod 1190 i 28. Den er i god Udvikling og har haft $10,000 \mathrm{Kr}$. Overskud. (H. ${ }^{20} / 3$ ). Rømøfærgen har under Østenvind stadig Standsninger paa Grund af Lavvande. (H. $3 / 1$ ).

Af Biler fandtes der i Sønderjylland 2706 Person-, 62 Rute-, 378 Droske- og 1183 Lastbiler, samt 780 Motorcykler. (H. ${ }^{18 / 11}$ ).

\section{Kommunalt.}

Byerne vurderedes 1927 i Millioner Kr. til: Haders- Aaben- Sønder- Tøn-

$\begin{array}{lcccc} & \text { lev } & \text { raa } & \text { borg } & \text { der } \\ \text { Grundværdi } & 12,7 & 10 & 11,4 & 4 \\ \text { Forsikringssum } & 63,4 & 38,6 & 48,4 & 25,3(\mathrm{H} .7 / \mathrm{s})\end{array}$

Aabenraas B u d g e t for ${ }^{30} / \mathrm{si}$ er $801,600 \mathrm{Kr}$. (H. $\left.{ }^{\mathrm{s}} / 2\right)$.

$\mathrm{Sk}$ at teprocenten var i

$\begin{array}{lllll} & \text { Haderslev } & \text { Aabenraa } & \text { Sønderborg } & \text { Tønder } \\ { }^{21} / 22 & 10 & 9 & 10 & 7 \\ { }^{20} / 30 & 7,8 & 8,5 & 11 & 6\left(\text { H. }{ }^{4} / 2\right) \\ { }^{20} / 31 & 7,5\left(\mathrm{H} .{ }^{19} / 3\right) & 8,2\left(\mathrm{H}^{27}{ }^{27} / 3\right) & 10,3\left(\mathrm{H}^{25} / 3\right) & \end{array}$

Udskrivningssummen for ${ }^{30} / 31$ er i Haderslev $680,000 \mathrm{Kr}$. (H. ${ }^{12} / 2$ ), i Sønderborg $789,865 \mathrm{Kr}$. $\left(\right.$ H. ${ }^{20} / 2$ ). 18/12).

Sønderborg optager et $\mathrm{L}$ a a n paa 1 Million Kr. (H.

Af større k o m m un le A rbejder nævnes Kloakering og Vandværk i Graasten (H. ${ }^{18} / 1$ ). Sit Elektricitetsværk sælger Byen til Sønderborg og Aabenraa Amters Elektricitetsforsyning for $112,000 \mathrm{Kr}$. (H. ${ }^{10 / 12}$ ). Tønder planlægger Gadearbejder til 100,000 Kr. (H. ${ }^{28} / 7$ ).

Sogneraadsformanden paa Rømø flk paa Grund af en meget omtalt Manupolation med en Kalklevering et Mistillidsvotum, men vil ikke vige for $\operatorname{det}(\mathrm{H} .7 / 1)$. Han blev for Resten senere frikendt af Navningeretten.

7. Menighedsliv.

Den $3 / 4$ lagdes Grundstenen til en ny $\mathrm{K}$ ir ke i Ringenæs (H. 4/4). B is k op Olesen i Ribe døde $12 / 4 \quad$ (H. $14 / 4$ ): Stiftsprovst Westergaard valgtes til hans Efterfølger med 810 Stemmer, mens L. Koch fik 706 (H. ${ }^{31 / 5}$, Av. ${ }^{31 / 5}$ ). Han Indskuddene i Sparekassen i Tinglev steg fra 84,000 til $129,000 \mathrm{Kr}$. (Av. $\left.{ }^{31} / \mathrm{s}\right)$.

Den $7 / 3$. vedtog Pengeinstitutterne i Haderslev $\mathrm{K}$ e $\mathrm{n}$ - 
udnævntes "1/. Statens Tilskud til Præsteembeder or 25,000 Kr., til tysk Præstebetjening 16,000 Kr. (H. ${ }^{8 / 10}$ ). Ved et V a lg til Menighedsraad i Sønderborg fik Tyskerne ved dansk Skødesløshed Flertallet af Stemmerne (H. ${ }^{27} / 11,{ }^{28} / 11$ ).

Af større kirkelige $\mathbf{M} ø \mathbf{d e r}$ foranstaltede Kirkeligt Samfund af 1898 et godt besøgt Møde i Aabenraa for hele Landsdelen (H. $\left.{ }^{23} / \mathrm{s}\right)$ : I Vedsted var et Sommermøde be-, sagt af ca. 1000 Mennesker (H. ${ }^{14} / 7$ ). Sammesteds holdtes det aarlige Efteraarsmøde (H. $\left.{ }^{2} / 211\right)$.

Til at forhandle med Myndighederne om ty ske kirkelige Ønsker og Krav udnæunte Kirkeministeren en fuldstændig tysk Kommission (H. $\left.{ }^{7} / \theta\right)$. Menighedsraadet i Frue Sogn i Haderslev gør Indsigelse mod denne ensidige Sammensætning (H. ${ }^{10 / 8}$ ).

I Aabenraa holdtes et af 700 Mennesker besøgt Møde til Drøftelse af Religionsundervisningen (H. ${ }^{25} / 8$ ).

\section{Oplys ning.}

I Folkeskolerne undervises 18,417 Børn paa Dansk, 2041 paa Tysk. Der gaar 421 i danske og 892 i tyske Privatskoler. Den danske Stat yder 696,854 Kr. til tysk Skolevæsen (H. $\% / 4$ ). I Haderslev By gaar 1782 Børn i Skole, deraf 412 i den tysksprogede (H. ${ }^{21 / 3}$ ). I Haderslev Amt var der i 19:9 7097 Børn i Skole, deraf 184 i private Skoler. Undervisning i Tysk gaves i 21 danske Skoler til 1456 Elever (H. ${ }^{15} / 7$ ). I Sønderborg Amt undervises 4505 Børn, deraf 455 i tysksprogede Afdelinger (H. ${ }^{28} / 3$ ). . I Tønder Amt er der 4916 Skolebørn mod 6551 i 1921. I de 19 Skoledistrikter med tyske Almueskoler er de tyske Elever sunket fra 1092 i 1923 til 901 i 1929 og de danske steget fra 960 i 1921 til 1254 i 1923,1142 i 1929 (H. 10/4, Av. ${ }^{16 / 4}$ ). I 139 af de dansksprogede Skoler gives der ogsaa Undervisning i Tysk. Hvis Staten overtager Merudgiften ved det dobbeltsprogede Skolevæsen, vil dens Udgift vokse med $60-70,000 \mathrm{Kr}$. (H. ${ }^{23} / 4$ ). Denne Overtagelse sker (H. ${ }^{5} ; 11$ ). Et Forslag om Endring af den sønderjydske Skoleordning, bl. a, det, at Kommunalbestyrelserne skulde have Indstillingsretten i Stedet for Skolekommisionerne, vækker stærk Modstand (H. $14 / 11,28 / 11,3 / 18$ ).

En ny Foredragsforening dannedes for det sydlige Als (H. $\left.{ }^{17} / 1\right)$.

Studentereksamen bestod i Sønderborg 26, Tønder 15, Haderslev 26. (Ber.)

Tønder Biblioteks forening har 316 Medlemmer, over 1900 Laanere og ca. 40.000 Udlaan (Av. ${ }^{11 / 5, ~ H . ~}$ 
9. Pressen.

Med "Berlingske Tidende"s Grundlæggelse af "Jydske Tidende" gøres der Forsøg paa Dannelse af en Bladtrust (H. $\left.{ }^{25} / 2,21 / 5\right)$. "Flensborg Avis« overgaar til et Aktieselskab med 315,000 Mark indbetalt Kapital (Av. ${ }^{8 / 5}$, H. ${ }^{8 / 5}$ ).

10. Personlig t.

- Af Dødsfald nævnes Jens Østergaard $\left(\mathrm{H}^{23} / \mathrm{i}\right)$, Kasper Jensen (H. $\left.{ }^{10} / 2\right)$, Pastor Prahl (H. ${ }^{2} / \%$, Kloppenborg Skrumsager (H. 1/10), Pastor Hansen, Dybbøl (H. 1/11), Redaktør P. Simonsen, Flensborg (Av. ${ }^{16 / 12}, H^{13} / 12$ ).

11. Andre Sager.

Af andre Sager skal nævnes: Øsby Sogn har haft ca. 150 Gravhøje, men har nu kun een vel bevaret (H. $1 / 1$ ). Oldtidsforskningen siden Genforeningen har store Resultater at opvise (H. ${ }^{17} / 1$ ). Ved "Cæcilielyst" ved Aabenraa findes en Mængde Urneskaar, vistnok fra 14. eller 15. Aarhundrede (H. ${ }^{11} / 4,{ }^{14} / 4,10 \%$. I en Grusgrav ved Ketting har man fundet 13 Grave fra Vikingetiden $\left(H .{ }^{17} / 12\right)$. Ved Sønderborg Slot har man fundet Grundvolden til Christian II.s Fangetaarn (H. ${ }^{25} / 6$ ). Sønderborg Byraad afviser med 10 Stemmer mod 9 ny Behandling af Sagen om det gamle Klosters Nedrivning $\left(\mathrm{H} .{ }^{22} / \mathrm{s}\right)$. I Vestslesvig foretages en Del Fredningsarbejder $\left(\mathrm{H} .{ }^{10} / \mathrm{a}\right)$. Ved Hedeby foretages store Udgravninger (Av. ${ }^{21 / 8}$ ).

Husbukkene hærger værre i sønderjylland end $i$ Nørrejylland (H. 1/2). I Tønder opførtes ${ }^{31} / 1$. et Stykke $i$ Tøndering Maal i Overværelse af Dansk Folkemaals Formand og Sekretær (H. 1/2). H. A. Brorsens Mindeplade $i$ Tonder flyttes hen til sin rette Plads i Storegade, Boghandler Nissens Hus (H. $\% / 4$ ). Oldefaderen til Violinbygger Hjort kom 1789 fra Haderslev til København (H. ${ }^{21} / 2$ ). Lærer Torp giver en Fremstilling af polske Mindretals Forhold (H. ${ }^{17} / 2,{ }^{21} / 2,{ }^{22} / 2$ ). Afstemningsopraabets Historie (H. ${ }^{7} / 2$ ).

\section{Rettelse.}

I Chr. Ilübbe: "De sønderjydske Pengeinstitutter efter Genforeningen «, $\$$. 20, Linje $18 \mathrm{fr}$. o. og følgende skal det hedde:

»5 \% indenlandske Statslaan af 1919." Dette Statslaan var paa 145 Mill. Kr. og gik i Almindelighed under Navnet "Genforeningslaanet", da det var tegnet med sønderjydske Formaal for Øje. Laanet blev tegnet til pari gennem offentligt Udbud. 